\title{
Unraveling the Molecular Mechanism of Selective Antimicrobial Activity of 2(5H)-Furanone Derivative against Staphylococcus aureus
}

\author{
Irshad S. Sharafutdinov ${ }^{1, *}$, Anna S. Pavlova ${ }^{1}$, Farida S. Akhatova ${ }^{2}$,
} Alsu M. Khabibrakhmanova ${ }^{3}$, Elvira V. Rozhina ${ }^{2}$, Yulia J. Romanova ${ }^{4}$, Rawil Fakhrullin ${ }^{2}{ }^{(D)}$, Olga A. Lodochnikova ${ }^{3,5}$, Almira R. Kurbangalieva ${ }^{3}$, Mikhail I. Bogachev ${ }^{6} \mathbb{C}$ and Airat R. Kayumov ${ }^{1, *(1)}$

1 Laboratory of Molecular Genetics of Microorganisms, Institute of Fundamental Medicine and Biology, Kazan Federal University, 18 Kremlyovskaya street, Kazan 420008, Republic of Tatarstan, Russia; anbio96@gmail.com

2 Laboratory of Bionanotechnology, Institute of Fundamental Medicine and Biology, Kazan Federal University, Kreml uramı 18, Kazan 420008, Republic of Tatarstan, Russia; farida125@mail.ru (F.S.A.); rozhinaelvira@gmail.com (E.V.R.); kazanbio@gmail.com (R.F.)

3 Biofunctional Chemistry Laboratory, Alexander Butlerov Institute of Chemistry, Kazan Federal University, 18 Kremlyovskaya street, Kazan 420008, Republic of Tatarstan, Russia; alsu-khabibrakhmanova@mail.ru (A.M.K.); lod_olga@mail.ru (O.A.L.); almira99@mail.ru (A.R.K.)

4 Interdisciplinary Centre for Proteomic Research, Institute of Fundamental Medicine and Biology, Kazan Federal University, 18 Kremlyovskaya street, Kazan 420008, Republic of Tatarstan, Russia; magnolina@list.ru

5 Arbuzov Institute of Organic and Physical Chemistry, FRC Kazan Scientific Center of RAS, 8 Arbuzov Street, Kazan 420088, Republic of Tatarstan, Russia

6 Biomedical Engineering Research Centre, St. Petersburg Electrotechnical University, St. Petersburg 197022, Russia; rogex@yandex.com

* Correspondence: irsultanovich@gmail.com (I.S.S.); kairatr@yandex.ru (A.R.K.); Tel.: +7-927-402-1105 (I.S.S.); +7-904-665-1908 (A.R.K.)

Received: 11 December 2018; Accepted: 3 February 2019; Published: 6 February 2019

\begin{abstract}
Staphylococcus aureus causes various infectious diseases, from skin impetigo to life-threatening bacteremia and sepsis, thus appearing an important target for antimicrobial therapeutics. In turn, the rapid development of antibiotic resistance and biofilm formation makes it extremely robust against treatment. Here, we unravel the molecular mechanism of the antimicrobial activity of the recently unveiled $\mathbf{F 1 0 5}$ consisting of three pharmacophores: chlorinated $2(5 \mathrm{H})$-furanone, sulfone, and $l$-menthol moieties. F105 demonstrates highly selective activity against Gram-positive bacteria and biofilm-embedded S. aureus and exhibits low risk of resistance development. We show explicitly that the fluorescent analogue of F105 rapidly penetrates into Gram-positive bacteria independently of their cell integrity and viability and accumulates there. By contrast, Gram-negative bacteria remain impermeable and, therefore, insusceptible to F105. Apparently, in bacterial cells, F105 induces reactive oxygen species (ROS) formation and nonspecifically interacts with a number of proteins, including ROS-utilizing ones. Using native and 2D PAGE, we confirm that F105 changes the charge of some proteins by either oxidation or direct interaction with them. Therefore, it seems justified to conclude that being simultaneously a ROS inducer and damaging proteins responsible for ROS utilization, F105 impairs the cellular anti-ROS defense representing a prospective ROS-inducing antibacterial agent.
\end{abstract}

Keywords: 2(5H)-furanones; biofilms; drug discovery; ROS; Staphylococci 


\section{Introduction}

While embedded into biofilm, bacteria appear to be strongly protected from various outer stresses such as antimicrobials and the immune system of the host $[1,2]$. To facilitate the treatment of biofilm-embedded pathogens, the combination of antibiotics with various agents repressing or destroying the biofilm has been suggested as a promising strategy [3]. Among various low molecular weight compounds being potential biofilm-repressing agents (for a detailed review see [3,4]) the derivatives of $2(5 \mathrm{H})$-furanone have been intensively investigated [5]. These compounds were originally described as a natural tool of red algae Delisea pulchra, repressing its biofouling [6,7]. It has been shown that various furanones can either be produced naturally by a variety of microorganisms and plants or synthesized chemically [8-10]. In cells, furanones participate in intra- and inter-species signaling and communication, and act as attractants, pheromones, and antimicrobials [11]. The discovery of their biofilm suppression activity [6,7] gave rise to intensive investigation of these compounds as biofilm-preventing agents $[5,6,12-14]$.

The biofilm-preventing activity of $2(5 H)$-furanone derivatives against Gram-negative bacteria is implemented through interference with molecules of autoinducer-1 (AI-1) [15-17] and autoinducer-2 (AI-2) [6,7], in particular by competitive replacement of $\mathrm{N}$-3-(oxohexanoyl)-L-homoserine lactone (AHL) from its receptor LuxR $[6,15]$. The molecular targets of $2(5 H)$-furanone derivatives in Gram-positive bacteria remain unknown. While no AHL-signaling is present in Gram-positive bacteria and inter-cellular communication in these microorganisms is governed by short peptides, various synthetic furanones suppress biofilm formation by Gram-positive S. epidermidis and B. subtilis, while the exact molecular targets are still unknown $[7,13,14,18]$. Thus, the response of $B$. subtilis to furanones has been reported to be QS-independent $[7,18]$. By contrast, some data support the idea that furanones somehow affect the QS-processes in Staphylococci. Thus, Zang et al. [19] have demonstrated that brominated derivative of furanone covalently binds and, thus, inactivates $S$-ribosylhomocysteine lyase LuxS, the enzyme of the autoinducer-2 synthesis pathway. Kuehl et al. [20] have also shown that LuxS could be a target for furanones in Staphylococci. On the one hand, the downregulation of luxS expression by subinhibitory concentrations of furanone was observed. On the other hand, in the luxS mutant that appeared more active in biofilm formation than its wildtype counterpart, no changes in the biofilm could be observed in the presence of furanones. Lönn-Stensrudet et al. reported that the bioluminescence of $V$. harveyi BB170 could be induced by S. epidermidis supernatant, which indicates that Staphylococci use AI-2 for communication. Of note, the induction of bioluminescence was not observed in the presence of furanones, and the biofilm-preventing activity of furanones against S. epidermidis was suppressed in the presence of (S)-4,5-dihydroxy-2,3-pentanedione (DPD), which is the precursor of AI-2. These data clearly demonstrate that bacterial quorum sensing seems to be one of the apparent targets of furanones also in Gram-positive bacteria. Besides their biofilm-preventing activity, some $2(5 H)$-furanone derivatives also exhibit antibacterial activities $[18,21,22]$, while the molecular targets of these compounds still remain unknown.

Here we show that 3-chloro-5(S)-[(1R,2S,5R)-2-isopropyl-5-methylcyclohexyloxy]-4-[4methylphenylsulfonyl]-2(5H)-furanone (F105), consisting of three pharmacophores including chlorinated $2(5 H)$-furanone, sulfonyl, and $l$-menthol moieties, exhibits antibacterial activity against biofilm embedded S. aureus by producing reactive oxygen species (ROS) and consequent damage of intracellular proteins.

\section{Results}

\subsection{Antimicrobial Spectrum of F105}

In the original research, the antimicrobial activity of 2(5H)-furanone F105 was reported only for S. aureus, while the compounds were active against both methicillin-sensitive and -resistant strains [21]. Extended assays of F105 revealed its highly specific antibacterial activity against Gram-positive bacteria. In particular, F105 at 8-16 $\mu \mathrm{g} / \mathrm{mL}$ repressed the growth and at $32 \mu \mathrm{g} / \mathrm{mL}$ killed $99.9 \%$ of the cells 
of S. aureus, S. epidermidis, B. cereus, B. subtilis, and M. luteus, while the growth of Gram-negative K. pneumoniae, S. marcescens, P. aeruginosa, and E. coli remained unaffected, even at $128 \mu \mathrm{g} / \mathrm{mL}$ of the compound (Table 1). S. aureus, B. cereus, S. marcescens, and K. pneumonia have been chosen for further investigations as representative nosocomial pathogenic bacteria with different shapes and cell wall structures.

Table 1. Antimicrobial spectrum of F105.

\begin{tabular}{ccc}
\hline & MIC, $\boldsymbol{\mu g} / \mathbf{m L}$ & $\mathbf{M B C}, \boldsymbol{\mu g} / \mathbf{m L}$ \\
\hline S. aureus & 8 & 32 \\
S. epidermidis & 16 & 32 \\
B. cereus & 8 & 32 \\
B. subtilis & 16 & 32 \\
M. luteus & 8 & 32 \\
K. pneumoniae & $>128$ & $>128$ \\
S. marcescens & $>128$ & $>128$ \\
P. aeruginosa & $>128$ & $>128$ \\
E. coli & $>128$ & $>128$ \\
\hline
\end{tabular}

\subsection{Synthesis of Fluorescent Compound 6 (F145)}

Next, to examine whether the observed inefficiency of F105 against Gram-negative bacteria is due to the absence of molecular targets or their impermeability to furanone, the F105 analogue possessing a fluorescent moiety and designed as F145 was synthesized (Figure 1). 5-[2-(Benzothiazol-2-yl)-4-bromophenoxy]-3-chloro-4-[(4-methylphenyl)sulfonyl]-2(5H)-furanone (6), studied compound F145) was prepared from commercially available mucochloric acid $\mathbf{1}$ as shown in Figure 1. The residue of 2-(benzothiazol-2-yl)-4-bromophenol (3) was chosen as the fluorophore and was synthesized from the reaction of 5-bromosalicylaldehyde with 2-aminothiophenol according to the known procedure [23]. Mucochloric acid methyl carbonate 2 was obtained as described previously [24]. The heating of compound 2 with phenol 3 in the presence of $\mathrm{CsF}$ in dichloromethane and subsequent purification of the reaction mixture by silica gel column chromatography led to isolation of the fluorophore-labelled furanone 4.
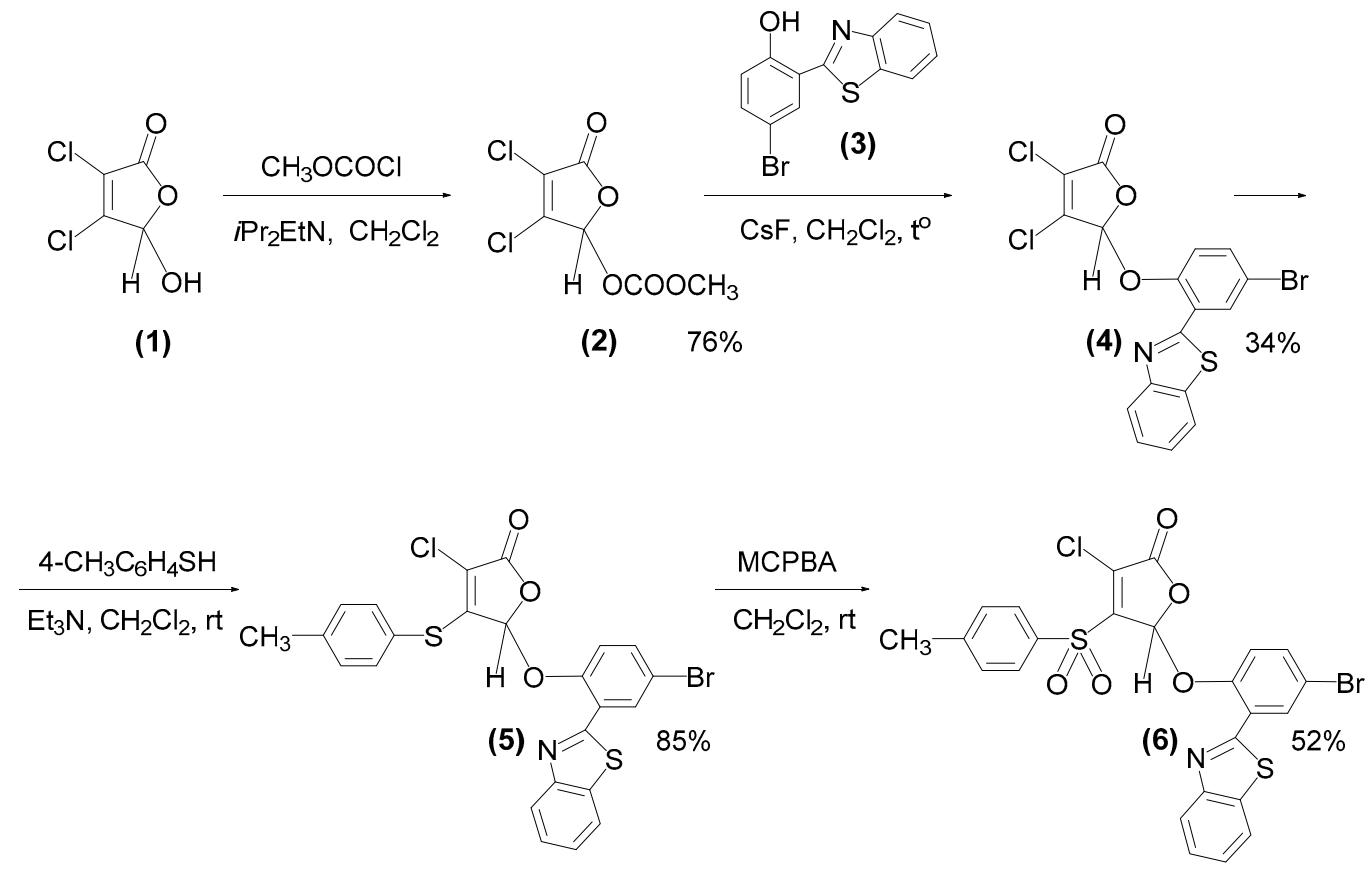

Figure 1. Synthesis of a fluorescent derivative of 2(5H)-furanone 6 (F145). 
At the next stage, a fragment of $p$-thiocresol was introduced into the molecule of compound 4 under basic catalysis. It is well-known that in the presence of triethylamine, reactions of thiols with mucochloric acid $\mathbf{1}$ and its 5-alkoxy derivatives proceed with the regioselective substitution of the chlorine atom in the fourth position of the lactone ring [25-27]. Thiolation reaction was performed in methylene chloride at room temperature with the equimolar ratio of the reactants and $\mathrm{Et}_{3} \mathrm{~N}$ (Figure 1). As a result, we isolated the novel thioether 5 with $85 \%$ yield. To obtain the corresponding sulfonyl derivative, compound $\mathbf{5}$ was exposed to $m$-chloroperbenzoic acid (MCPBA). The reaction was carried out in dichloromethane at room temperature using an excess of oxidant resulting in the novel fluorescent sulfone of 2(5H)-furanone series 6 (F145). Structures of all synthesized compounds were elucidated using ${ }^{1} \mathrm{H},{ }^{13} \mathrm{C}\left\{{ }^{1} \mathrm{H}\right\}$ NMR spectroscopy and HRMS (Figures S1-S4).

In addition, the molecular and crystal structure of furanone 6 was characterized using single crystal X-ray diffraction (Figure 2). According to the X-ray data, compound 6 is represented by the chloroform solvate in the examined crystal in the main compound/solvent ratio $=2: 1$. The chloroform molecule in the crystal is in the special position in the center of symmetry. The overall conformation of the molecule 6 can be described as cisoid —aromatic substituents are situated on one side of the plane of the heterocyclic fragment.

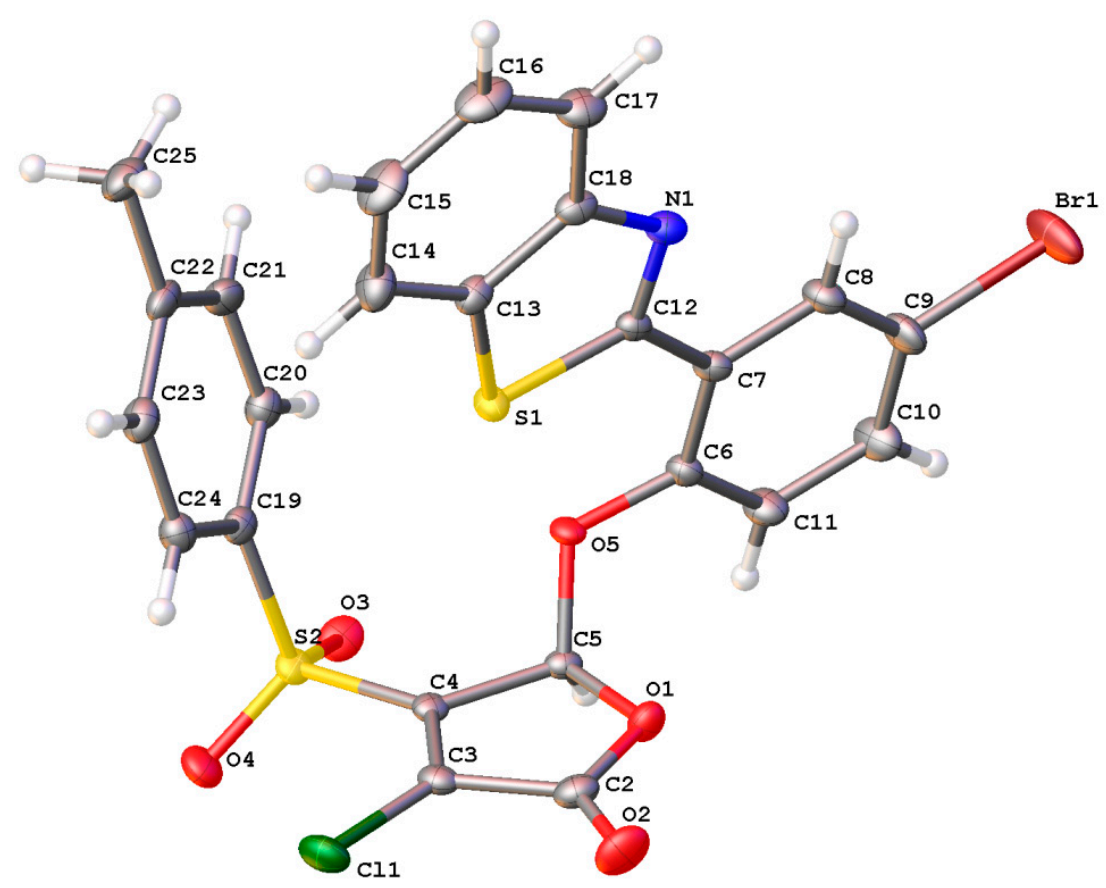

Figure 2. Molecular structure of compound 6 (F145) in the crystal.

\subsection{Penetration of $\mathbf{F} \mathbf{1 0 5}$ Analogue into Bacterial Cells}

The substitution of $l$-menthol by fluorescent moiety drastically reduced the antibacterial activity of F145. Its MICs for all Gram-positive bacteria became $128 \mathrm{mg} / \mathrm{L}$ and higher, confirming the strong requirement of $l$-menthol pharmacophore for activity, as was shown earlier $[18,21]$. Nevertheless, the planktonic bacteria were treated with F145 for $30 \mathrm{~min}$ and its penetration into the cells was assessed with CLSM (Figure 3). Cells were presumed as viable (Figure 3a) due to the fact that only single occurrences of red-stained (dead) cells were observed (Figure 3b). In accordance with antibiotic susceptibility test results (Table 1), the blue fluorescence of F145 was observed only in S. aureus and B. cereus. Moreover, as long as $\mathrm{DioC}_{6}$ dye stains bacterial cell membrane and accumulates in the cell edge, F145 fluorescence is distributed evenly in the cells (Figure 3c), which strongly suggests that F145 penetrates into the cell and accumulates there. Notably, as can be observed in spatial overlap between three fluorescent labels (Figure 3d), F145 was detected in both alive and dead S. aureus and B. cereus 
cells. These data clearly indicate that F145 easily permeates the cell membrane S. aureus and B. cereus, but $S$. marcescens and K. pneumonia seem to remain impermeable for the furanone.

\section{S. aureus}

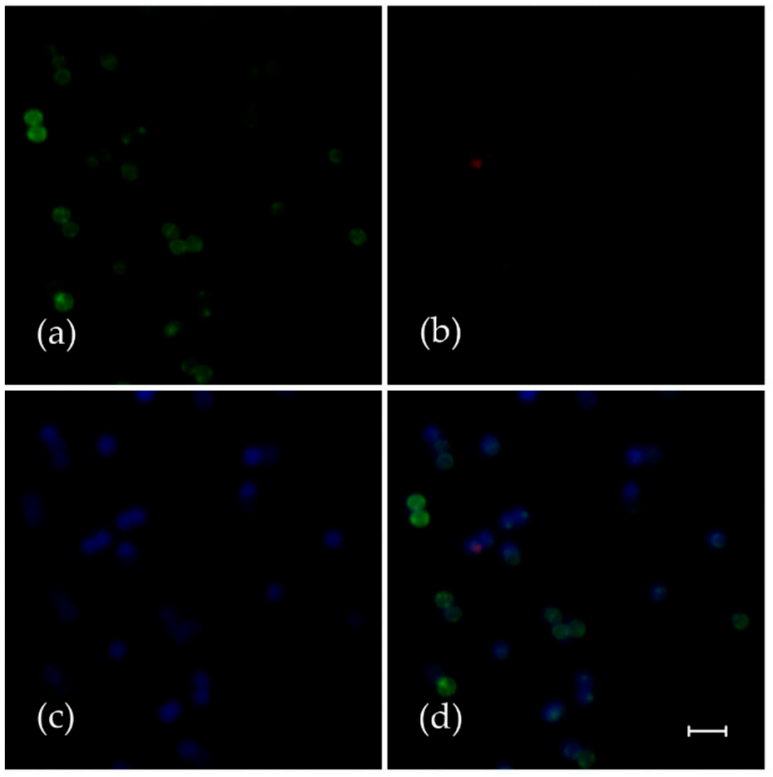

K. pneumoniae

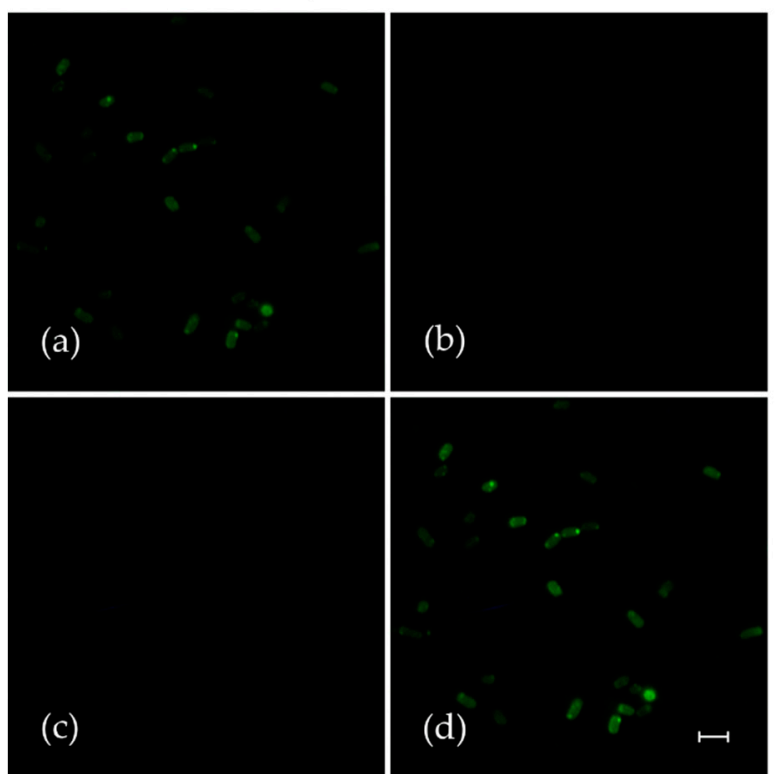

\section{B. cereus}

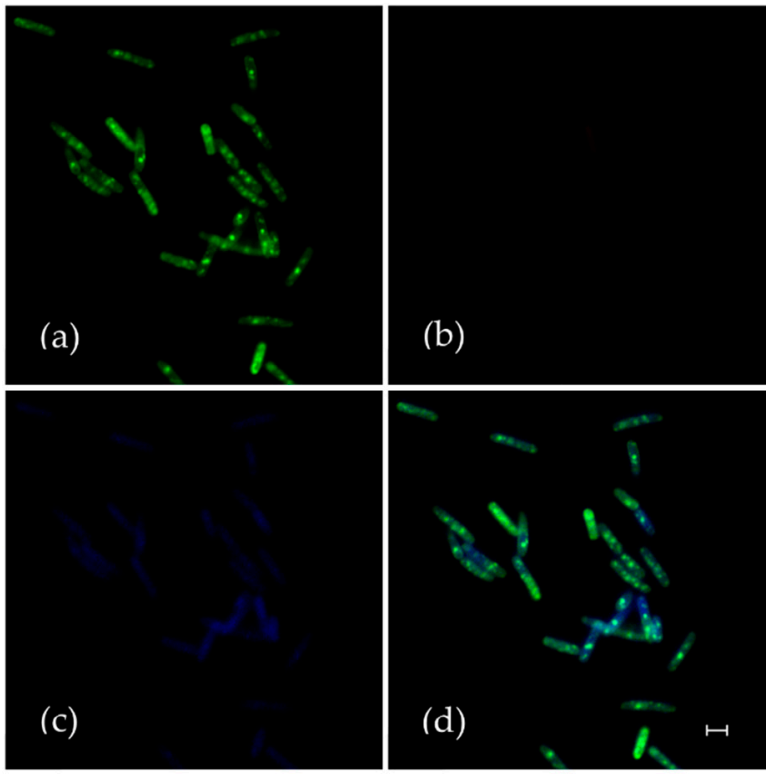

S. marcescense

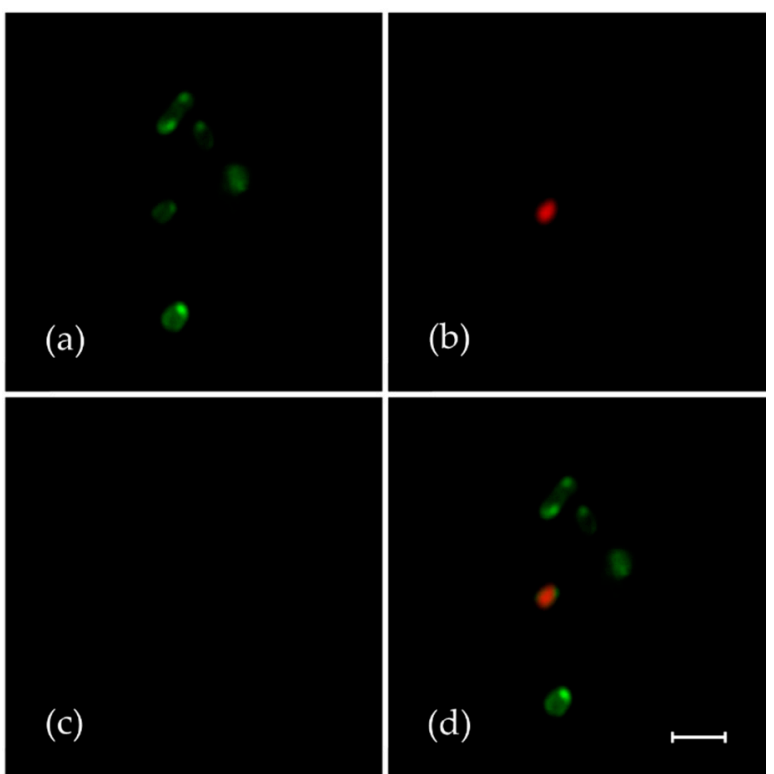

Figure 3. The analysis of fluorescent F105 analogue (F145) penetration into planktonic bacterial cells. Gram-positive (S. aureus and B. cereus) and Gram-negative (S. marcescens and K. pneumonia) bacteria were grown for $24 \mathrm{~h}$ with agitation in MH broth, then washed and resuspended in PBS. F145 was added until the final concentration of $10 \mu \mathrm{g} / \mathrm{mL}$ (close to MIC of F105 for Gram-positive bacteria), and incubation was followed for the next $15 \mathrm{~min}$. Then, the cells were live/dead stained with $\mathrm{DioC}_{6} / \mathrm{PI}$ (additional $15 \mathrm{~min}$ ) and analyzed with confocal laser scanning microscopy. Images show the fluorescence of $\mathrm{DioC}_{6}$ (a), PI (b), F145 (c) and the combination of all channels (d). The scale bars indicate $2.5 \mu \mathrm{m}$.

\subsection{Penetration of F105 Analogue into S. aureus Biofilm}

Earlier we have shown that F105 efficiently eradicates the mature biofilms of S. aureus providing complete death of biofilm-embedded S. aureus at $4 \times \mathrm{MBC}$ [21]. To investigate the diffusion ability 
of $2(5 H)$-furanone derivative into the biofilm matrix, S. aureus cells were grown in MH broth for $24 \mathrm{~h}$ under static conditions to obtain a mature biofilm, and F145 was added until final concentration of $10 \mu \mathrm{g} / \mathrm{mL}$. After $1 \mathrm{~h}$ of incubation, the biofilm was analyzed with CLSM. The fluorescence of F145 could be observed throughout all layers of the $S$. aureus biofilm of approximately $20 \mu \mathrm{m}$ thickness, indicating rapid penetration of the furanone through the biofilm matrix (Figure 4). Moreover, fluorescence signal demonstrated homogeneous distribution of F145 through the biofilm (Figure 4b) with the predominant accumulation within individual bacterial cells including bottom layers.
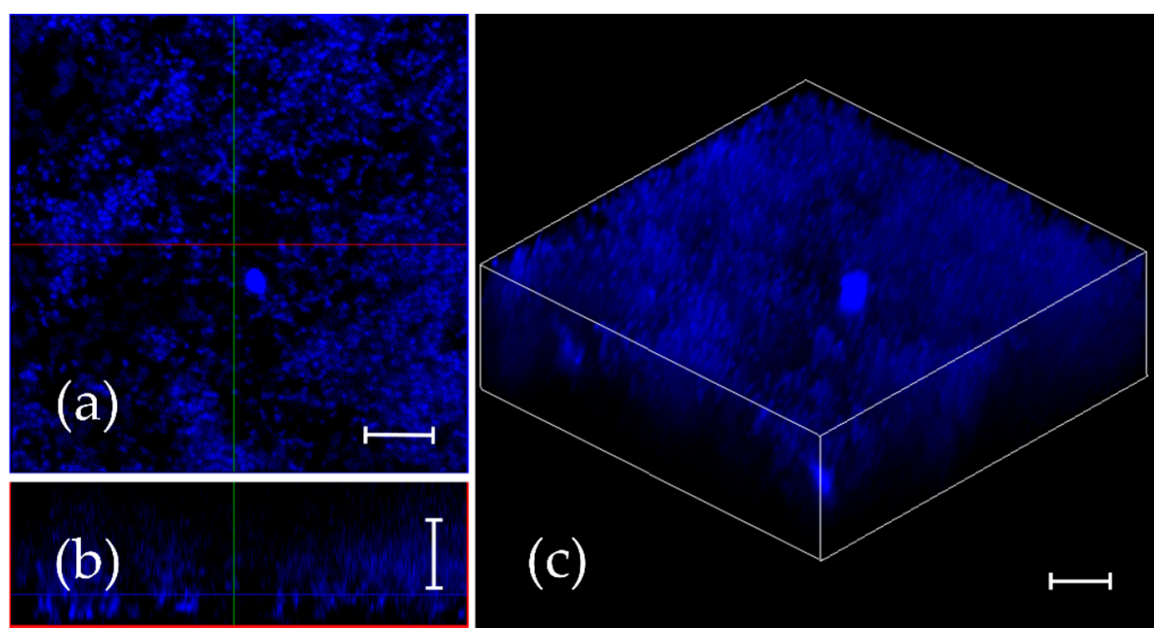

Figure 4. F145 diffusion into the mature S. aureus biofilm. The $24 \mathrm{~h}$ old biofilm was treated with F145 for $1 \mathrm{~h}$ and analyzed with confocal laser scanning microscopy using a single-channel mode. (a) X; Y orientation of the biofilm; (b) Z-stack of the biofilm; (c) 3D-model of the biofilm. The scale bars indicate $10 \mu \mathrm{m}$.

\subsection{Reactive Oxygen Species (ROS) Induction}

Considering the fact that F105 contains a chemically active sulfonyl group, we supposed that it might behave as oxidizing agent and probably induce ROS formation. To check this assumption in vivo, we used a cell-permeable $2^{\prime}, 7^{\prime}$-dichlorofluorescin diacetate (DCFDA), which provides sensitive and rapid quantitation of ROS in response to oxidative metabolism. As could be seen from Figure 5, F105 at the concentration of $32 \mu \mathrm{g} / \mathrm{mL}$ (corresponding to its MBC) led to the significant induction of fluorescence only in S. aureus and B. cereus. In S. marcescens and K. pneumonia the fluorescence was comparable with untreated cells (Figure 5). These data clearly indicate that F105 causes oxidative stress, which probably leads to oxidation of proteins and consequent cell death. 

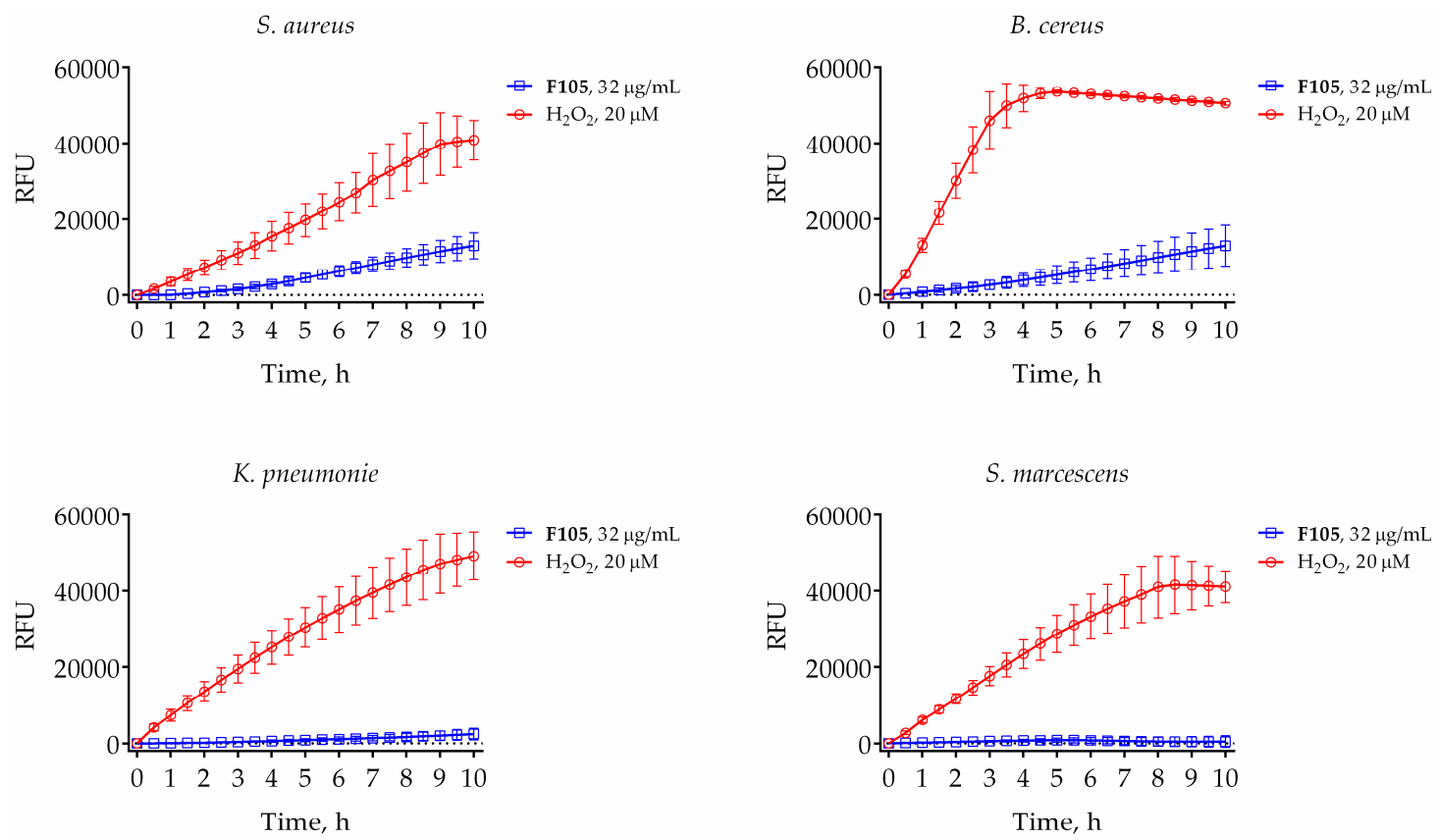

Figure 5. Dynamics of reactive oxygen species (ROS) production in bacteria induced by $20 \mu \mathrm{M}$ of hydrogen peroxide (red line) or $32 \mu \mathrm{g} / \mathrm{mL}$ of F105 (blue line). Black line stands for untreated control cells. Bacterial cells were grown for $18 \mathrm{~h}$, harvested, and washed with PBS. Cells were re-suspended until the final density of $10^{5} \mathrm{CFU} / \mathrm{mL}$ in PBS supplemented with $2^{\prime}, 7^{\prime}$-dichlorofluorescin diacetate (DCFDA) $(5 \mu \mathrm{M})$. After $30 \mathrm{~min}$ of pre-incubation at $25^{\circ} \mathrm{C}, 32 \mu \mathrm{g} / \mathrm{mL}$ F105 or $20 \mu \mathrm{M} \mathrm{H}_{2} \mathrm{O}_{2}$ were added and the fluorescence was measured for $9 \mathrm{~h}$ with 5 -min time intervals.

\subsection{Effect of $\mathbf{F 1 0 5}$ on Membrane Potential}

Cell membrane damage, a well-known mechanism of antimicrobial activity exhibited by both ROS and various antimicrobials including quaternary ammonium salts and the lipopeptide antibiotic daptomycin [28], is followed by a drop of the membrane potential. Since ROS production could result in damage of both the intracellular proteins and the membrane, the changes in membrane potential of bacterial cells in response to F105 treatment was measured by detection of $\mathrm{DioC}_{2}$ fluorescence. As a control, bacteria were treated with benzalkonium chloride (BAC), a quaternary ammonium compound which destroys bacterial cells by disrupting its cell membrane. In cells with an intact electrical potential gradient, the green fluorescence of $\mathrm{DioC}_{2}$ could be observed. As expected, $4 \mu \mathrm{g} / \mathrm{mL}$ of BAC (corresponding to its $\mathrm{MBC}$ for $S$. aureus) led to significant decrease of fluorescence in all treated cells, although with different ranges, suggesting that the membrane potential decreases due to membrane integrity damage (Figure 6). In the presence of F105, the fluorescence level in S. aureus and B. cereus also drastically decreased in comparison with untreated control cells. In marked contrast, in S. marcescens and K. pneumonia the fluorescence remained almost unchanged in the presence of F105, suggesting that their membranes remained unaffected and intact (Figure 6). These data further confirm the specificity of F105 activity against Gram-positive bacteria. 

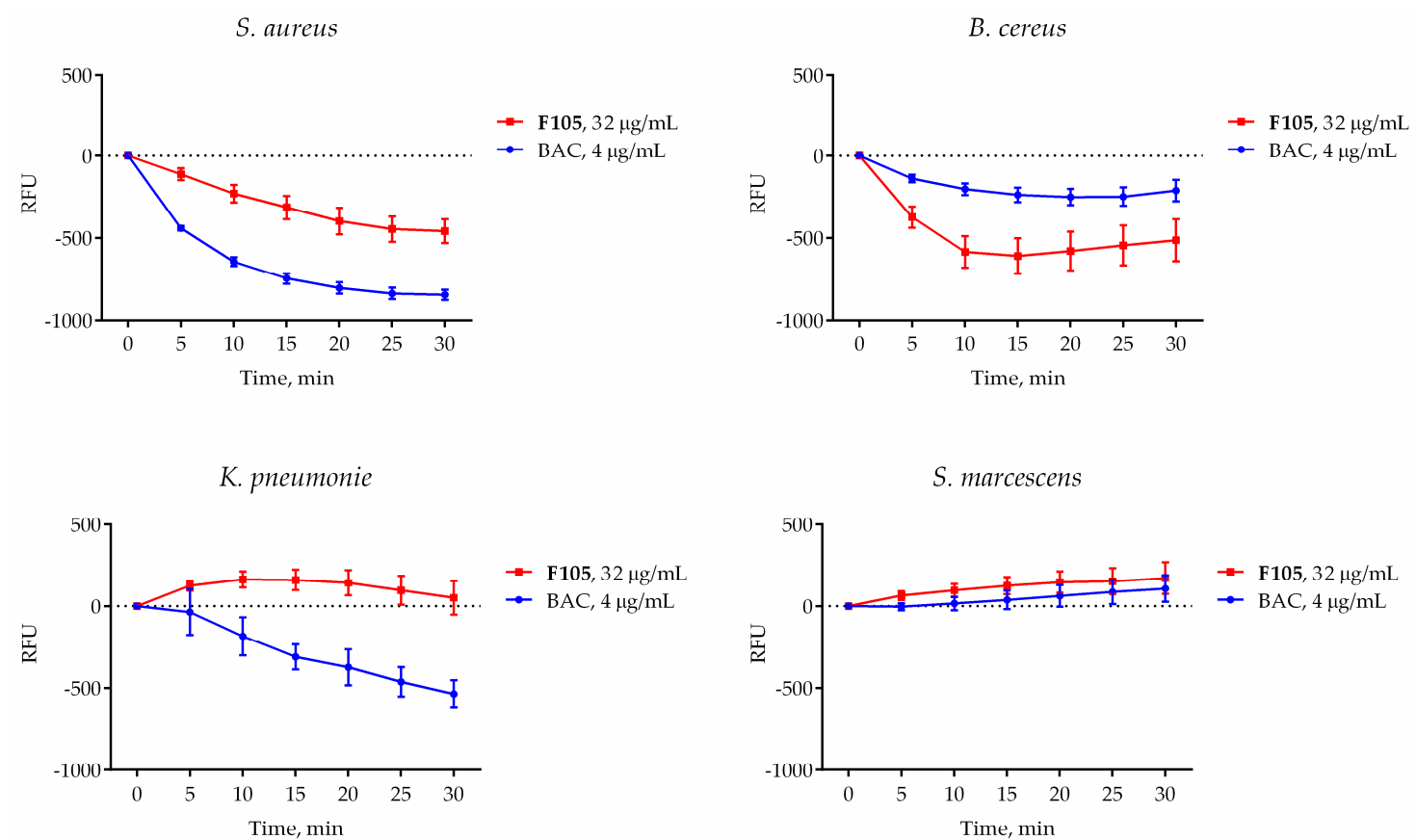

Figure 6. The effect of F105 (blue line) and benzalkonium chloride (red line) on the membrane potential of bacterial cells. Bacteria were grown for $18 \mathrm{~h}$, harvested, and washed with PBS. Cells were re-suspended until the final density of $10^{5} \mathrm{CFU} / \mathrm{mL}$ in PBS supplemented with $\mathrm{DioC}_{2}(10 \mu \mathrm{M})$. After 30 min preincubation at $25{ }^{\circ} \mathrm{C}, \mathrm{F} 105$ or BAC were added until final concentrations of 4 or $32 \mu \mathrm{g} / \mathrm{mL}$, respectively (corresponding to their respective MBCs), and the fluorescence was measured for $30 \mathrm{~min}$ with 5-min intervals. Black dashed line indicates the same data for the untreated control cells.

\subsection{Effect of $\mathbf{F 1 0 5}$ on S. aureus Cell Integrity}

Additionally, the integrity of $S$. aureus cells after F105 treatment was analyzed using AFM. S. aureus cells were treated for $18 \mathrm{~h}$ with $1 \times$ MBC of $\mathbf{F 1 0 5}(32 \mu \mathrm{g} / \mathrm{mL})$ and then analyzed with atomic force microscopy. As a control, cells were treated with BAC.

The exposition of cells to BAC at $1 \times \operatorname{MBC}(4 \mu \mathrm{g} / \mathrm{mL})$ led to visible cell wall damage and leakage of cell content (Figure 7): cells were characterized with roughened or even split surfaces (shown with transparent arrows), and cell debris particles/organic substances were observed around the cells (shown with a white arrows). At the same time, F105 at bactericidal concentration $(32 \mu \mathrm{g} / \mathrm{mL}$ ) led to the same rate of CFU decrease (Table 2) but did not lead to any visible destruction of the surfaces of the treated S. aureus cells (Figure 7). Furthermore, no leakage of the intracellular content and cell debris could be observed, which suggests that the cell wall remained intact, in contrast to the BAC treatment (Figure 7). These data suggest that F105 most likely do not directly target the membrane or the cell wall of bacteria.

Table 2. CFUs number of $S$. aureus after $18 \mathrm{~h}$ treatment.

\begin{tabular}{ccc}
\hline Control & F105, 32 $\mu \mathrm{g} / \mathrm{mL}$ & BAC, $4 \mu \mathrm{g} / \mathrm{mL}$ \\
\hline $7 \times 10^{9}$ & $2 \times 10^{5}$ & $5 \times 10^{5}$ \\
\hline
\end{tabular}



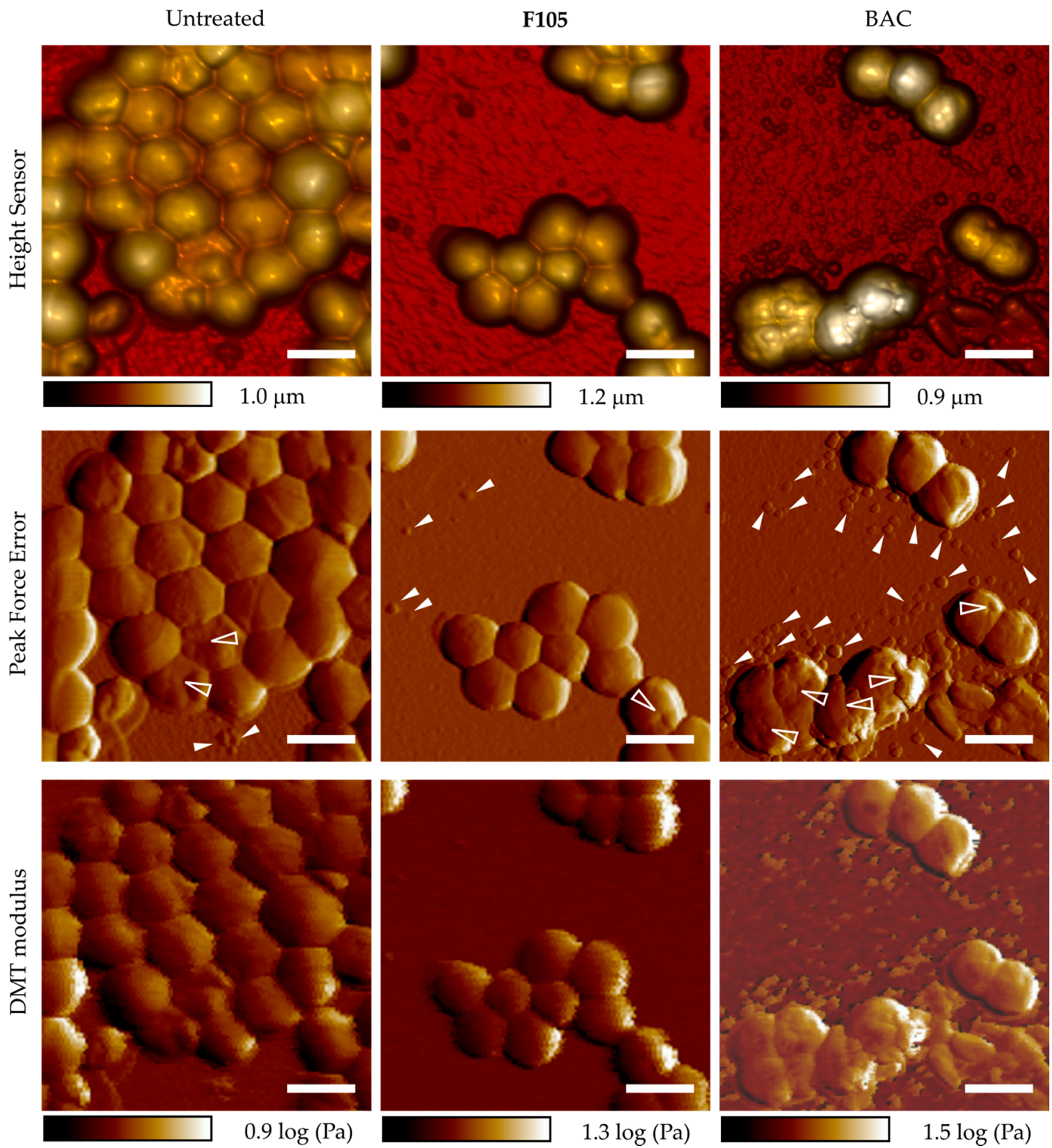

Figure 7. Atomic force microscopy (peak force tapping mode) images of $S$. aureus planktonic cells after $18 \mathrm{~h}$ incubation with $4 \mu \mathrm{g} / \mathrm{mL}$ of BAC or $32 \mu \mathrm{g} / \mathrm{mL}$ of $\mathbf{F 1 0 5}$ (in correspondence with their respective MBCs). Scale bar is $2 \mu \mathrm{m}$. Cell wall damage is shown with transparent arrows; cell debris particles and organic substances are shown with white arrows).

\subsection{F105 Nonspecifically Interacts with a Number of Intracellular Proteins of S. aureus}

Only a few investigations have reported about the molecular targets of $2(5 H)$-furanone derivatives in Gram-positive bacteria [13,18,19]. To characterize the mechanism of F105 antibacterial activity, we investigated changes in the S. aureus proteome induced by exposition to F105. For that reason, bacterial cells were grown with shaking for $24 \mathrm{~h}$ at $37^{\circ} \mathrm{C}$ in the presence of a sub-lethal concentration (MIC) of F105, and then harvested. Crude extracts from treated and non-treated cells were prepared, stained with Cy5 and Cy3 respectively, and separated by two-dimensional electrophoresis (Figure S5). The observed domination of green spots on a gel suggested significant down-regulation of many proteins in cells when grown in the presence of sub-lethal F105 concentrations $(8 \mu \mathrm{g} / \mathrm{mL})$. The green-stained spots (proteins which are present only in control cells) and the red-stained spots 
(proteins expressed in response to F105 treatment) were excised and identified with LC-MS. Among down-regulated proteins, 13 proteins were identified in each of the three independent experiments (Table S2). The identified proteins are known to be involved in many different cellular processes, from energy metabolism and DNA synthesis to protein folding and cell stress response, and they do not belong to any particular molecular pathway. Similarly, the up-regulated proteins (Table S3) also did not show belonging to any single group, supposing non-specific interaction of F105 with cellular proteins.

The negatively charged sulfonyl group of F105 was supposed to interact with positively charged amino acids of proteins. In this case, one could expect the changes in both charge and conformation of the protein and consequent changes in its electrophoretic mobility under native conditions. To test whether F105 is able to interact with proteins, the crude extract of $S$. aureus was treated with F105 $(64 \mu \mathrm{g} / \mathrm{mL})$ for $1 \mathrm{~h}$ at $37^{\circ} \mathrm{C}$ and the electrophoretic mobilities of proteins from treated and non-treated extracts were compared using 2D-electrophoresis (Figure S6). Again, a number of green and red spots were detected, suggesting that F105 interacts in vitro with some proteins leading to the changes in their charges and consequent in-gel mobility shift during the first separation by the isoelectric point (pI) value of the protein. The protein spots stained in green and red were also isolated and identified with LC-MS (Table S4).

Interestingly, five proteins including enolase, molecular chaperone GroEL, inosine-5monophosphate dehydrogenase, thioredoxin reductase, and branched-chain alpha-keto acid dehydrogenase were identified also in vivo (Table S2), suggesting that they preferentially interact with F105.

In an attempt to characterize the putative substrates for F105, some characteristics of proteins with changed mobility identified both in vivo and in vitro were predicted in silico and compared with the translated proteome of S. aureus (Figure 8). The statistical analysis revealed that typical molecular weights, hydrophobicity, aliphatic, and instability indexes of the proteins identified as putative substrates for F105 did not have a statistically significant difference from those characteristics calculated for translated proteome. By contrast, these proteins had acidic $\mathrm{pI}$ values of around 5.2 and slightly negative charge under physiological $\mathrm{pH}$, which is considerably lower than typical values of whole proteome. This data suggests that F105 might preferentially interact with acidic, negatively charged proteins.
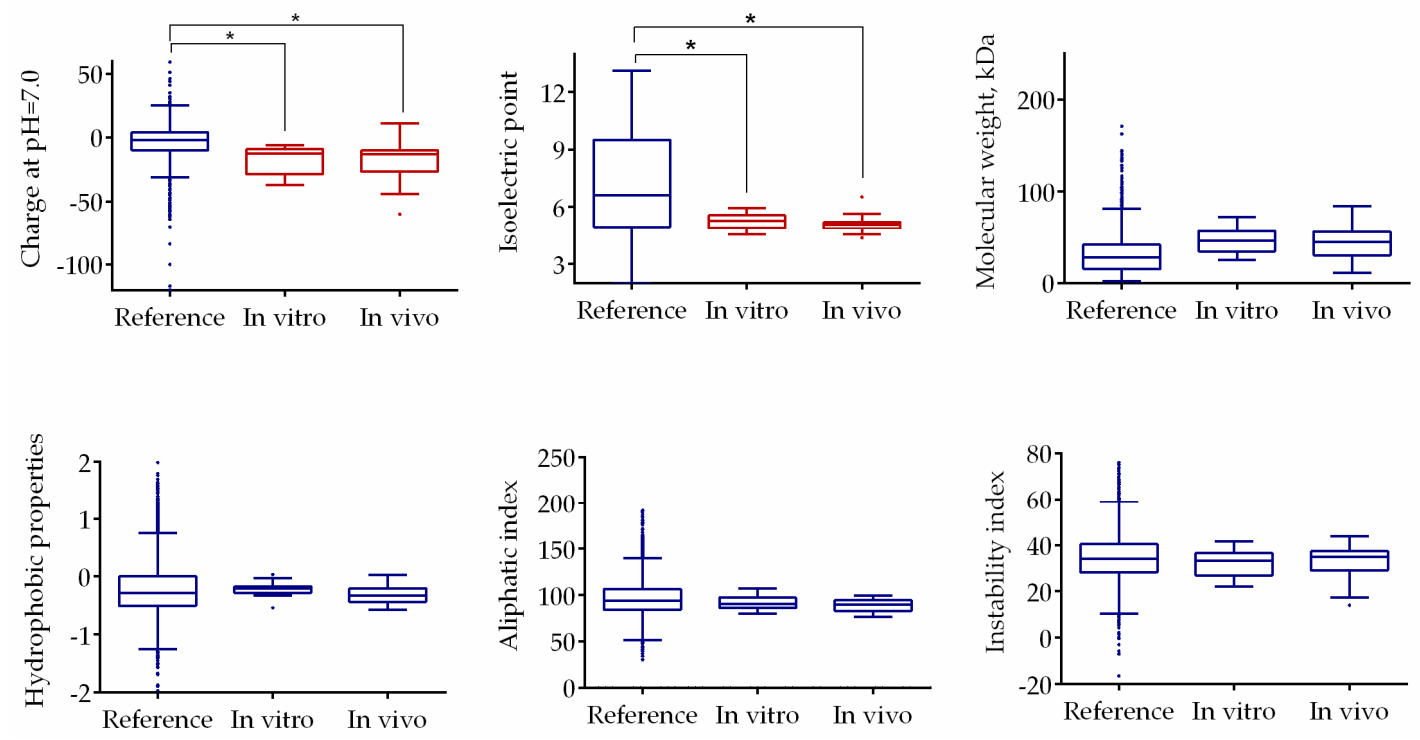

Figure 8. Comparison of physical and chemical properties of the putative substrates for the interaction with F105 with translated S. aureus proteome. Asterisks denote statistically significant differences of medians $(* p<0.05)$. 
To check the assumption that F105 could interact with proteins, a number of proteins with a pI lower than 7 and negative charge were treated with F105 and separated with native PAGE in comparison with non-treated samples (Figure 9). Significant changes in migration of F105-treated small heat-shock protein IbpA from Acholeplasma laidlawii (calculated relative mobility change index $0.971 \pm 0.015$ ) and glutamine synthetase from Bacillus subtilis (calculated relative mobility change index $0.979 \pm 0.004$ ) were detected (Table 3). A slight shift in mobility was observed for DNAase and BSA. These data are in agreement with previous observation that F105 interacts with proteins and apparently damages their structural or physical-chemical properties leading to the consequent cell death.

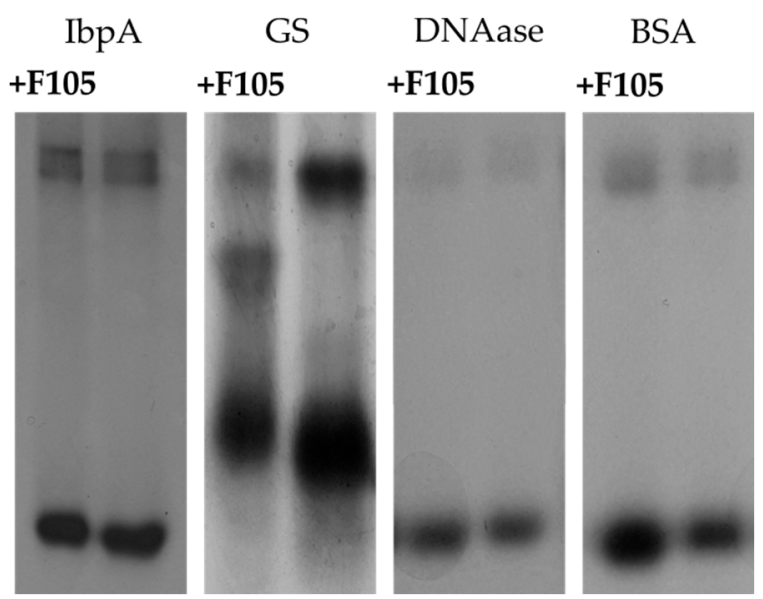

Figure 9. The electrophoretic separation of non-treated and F105-treated proteins under native conditions.

Table 3. Properties of proteins.

\begin{tabular}{ccccc}
\hline Protein & IbpA & GS & DNAase & BSA \\
\hline Charge & -2.3 & -18.5 & -8.1 & -9.9 \\
pI & 5.7 & 5.1 & 5.3 & 6.2 \\
Relative mobility change index & $0.979 \pm 0.004$ & $0.971 \pm 0.015$ & $1.016 \pm 0.005$ & $1.017 \pm 0.004$ \\
\hline
\end{tabular}

\section{Discussion}

To date, molecular targets and mechanisms of $2(5 H)$-furanone derivatives activity against Gram-positive bacteria remain unknown. This work attempts to identify the molecular targets for the 2(5H)-furanone derivative F105 [21], which consists of three pharmacophores including chlorinated 2(5H)-furanone, sulfonyl, and $l$-menthol moieties, and exhibits both biofilm suppression and antibacterial activity against Gram-positive bacteria (Table 1).

Firstly, we have shown that the novel synthesized furanone F145, the fluorescent analogue of F105, quickly penetrates into the cell of Gram-positive bacteria (S. aureus and B. cereus) and accumulates there, while Gram-negative S. marcescens and K. pneumonia remain seemingly impermeable for the furanone (Figure 3). Probably, the overall negatively charged F105 competes with negatively charged lipopolysaccharides of the outer membrane of these Proteobacteria. Interestingly, F145 was detected in both viable and dead cells of $S$. aureus, leading to the assumption that the furanone penetrates the cell membrane independently of its integrity and cell viability.

It has been shown previously that the removal of $l$-menthol or sulfonyl moieties completely suppressed the compound activity $[18,21]$. Since the $l$-menthol was reported to affect the cell membrane [29] by disruption of the interlamellar hydrogen-bonding network at the polar head group region in the model lipid system [30], it was speculated that the $l$-menthol moiety facilitates rapid diffusion of F105 into the biofilm matrix and probably through the cell membrane being efficient 
against both planktonic and biofilm-embedded S. aureus cells [21]. While F145 lacks the $l$-menthol moiety (Figure 1), it was also capable of rapidly diffusing into the lower layers of the biofilm (Figure 4), suggesting that $l$-menthol is not responsible for this property. Moreover, while rather uniformly distributed fluorescence of F145 in the treated S. aureus and B. cereus cells could be observed (Figure 3b), neither visible damage of cells nor leakage of the intracellular content could be observed using AFM in the F105-treated S. aureus, in marked contrast to BAC treatment (Figure 7). Taken together, these data suggest that furanones including F105 most likely do not directly target the membrane and probably interact with soluble intracellular protein(s).

Next, since the furanone F105 possesses a sulfonyl pharmacophore which is known to be chemically active as an oxidizing agent, we suggested that the possible induction of ROS formation in the F105-treated cells could play a key role. Indeed, the measurements revealed significant increase of DCFDA fluorescence in the F105-treated S. aureus and B. cereus cells (Figure 5), suggesting ROS formation activation. As additional confirmation of this hypothesis, the induction of heme peroxidase in the F105-treated cells could be noted (Table S3). Moreover, the observed decrease of membrane potential in the F105-treated S. aureus and B. cereus cells (Figure 6) could be a consequence of the membrane damage by the ROS. In agreement with no visible indication of $\mathbf{F 1 4 5}$ penetration into Gram-negative S. marcescens and K. pneumonia, for these bacteria neither ROS formation nor decrease of the membrane potential in the presence of F105 could be observed (Figures 5 and 6).

In recent years, multiple reports indicated rapid development of antibiotic resistance by S. aureus [31], which further speeds up in biofilms [2,32]. To identify the intracellular targets of F105, we attempted to obtain a resistant strain. Fourteen serial passages of S. aureus on F105-containing media did not lead to the development of resistant cells (not shown). On the one hand, only a few antibiotics are effective against $S$. aureus persistent biofilms [1,33], therefore, F105 seems a promising antimicrobial with low risk of resistance development and highly specific efficiency against biofilm-embedded staphylococci. On the other hand, the classical approach for target identification by comparison of the respective genome or proteome of a sensitive and resistant strain was not available. Therefore, to identify the possible mechanism of F105 activity, S. aureus cells were treated with sublethal concentrations of furanone for $24 \mathrm{~h}$ and changes in the proteome were later analyzed. As indicated in Tables S2 and S3, the proteins with changed abundance in treated cells could not be unambiguously identified as belonging to any single group, neither using functional nor pathway-based classification (see Figure S5, Tables S2 and S3). As a control, the crude extract of S. aureus was treated with F105 to evaluate the possibility of direct interactions of furanone with proteins (Figure S6). Again, a number of proteins from the treated extract changed their gel mobility (Table S4), most likely because of the charge alterations caused by the interaction with furanone. It should be further noted that five proteins including enolase, molecular chaperone GroEL, inosine-5-monophosphate dehydrogenase, thioredoxin reductase, and branched-chain alpha-keto acid dehydrogenase were identified both in vivo and in vitro, suggesting that the observed proteome changes (Figure S6) were caused by direct interactions with F105. As confirmation of this hypothesis, the comparative analysis revealed high identity of various biochemical properties of these potential substrate proteins (Figure 8). Moreover, the electrophoretic mobility of four individual proteins with $\mathrm{pI}$ and charge values close to those of the putative F105 substrates were changed after $1 \mathrm{~h}$ of F105 treatment (Figure 9, Table 3), suggesting that F105 could interact with them and affect their properties. Notably, the majority of proteins of $S$. aureus affected by F105 both in vivo and in vitro were enzymes with positively charged amino acids in their active centers (either His, Lys or Arg), which could interact with furanone as shown in [34]. These data together with the fact of Heme peroxidase induction in the F105-treated cells (Table S3) strongly support the hypothesis that F105 induces the reactive oxygen species (ROS) production with apparent consequent oxidation of proteins. Nevertheless, while the mobility of glutamine synthetase was changed after treatment with F105 (Figure 9), no significant changes in the enzymatic activity could be observed (not shown), suggesting that F105 does not necessarily bind with the enzyme's active center but rather damages the protein structure by yet another mechanism. 
Finally, among the proteins affected by F105 both in vivo and in vitro, we identified two molecular chaperons, GroEL and DnaK, responsible for the protein folding under stress conditions and a set of enzymes responsible for the oxidized proteins reduction (Tables S2-S4). Thus, being on the one hand the ROS inducer, on the other hand, F105 might bind proteins that are responsible for ROS utilization, thereby damaging the cellular anti-ROS defense. Consequent oxidation of other enzymes involved in common metabolism may lead to their irreversible damage and cell death.

To conclude, F105 might penetrate the cells and induce oxidative stress, making resistance development highly unlikely. Current development of ROS delivery/induction methods that would be free of side effects for the host tissues represent a promising approach for the topical treatment of infections caused by drug-resistant pathogens [32]. Accordingly, we believe that F105 is capable of intracellular ROS induction activation and is a promising candidate as a ROS inducing antibacterial agent.

\section{Materials and Methods}

\subsection{Strains and Growth Conditions}

Antibacterial activity of F105 was evaluated on a number of Gram-positive (methicillin sensitive Staphylococcus aureus subsp. aureus ATCC ${ }^{\circledR} 29213$ and Bacillus cereus (clinical isolate)) and Gram-negative (Serratia marcescens and Klebsiella pneumoniae (clinical isolates)) bacteria. Clinical isolates were obtained from the Kazan Institute of Epidemiology and Microbiology (Kazan, Russia). The bacterial strains were stored in $10 \%(\mathrm{~V} / \mathrm{V})$ glycerol stocks at $-80{ }^{\circ} \mathrm{C}$ and freshly streaked on blood agar plates (BD Diagnostics, Franklin Lakes, NJ, USA) and grown overnight at $35{ }^{\circ} \mathrm{C}$ before use. Fresh colony material was used to adjust an optical density of 0.5 McFarland (equivalent to $10^{8}$ cells $/ \mathrm{mL}$ ) in $0.9 \% \mathrm{NaCl}$ solution that was used as a working suspension and inoculated in Muller-Hinton (MH) broth (Sigma-Aldrich, St. Louis, MO, USA) until final concentration of $10^{5}$ cells $/ \mathrm{mL}$. Benzalkonium chloride (Sigma, St. Louis, Mo, USA) was used as a reference antimicrobial.

\subsection{Determination of Minimal Inhibitory (MIC), Minimal Bactericidal Concentrations (MBC) and Resistance Development}

The minimum inhibitory concentration (MIC) of F105 was determined by the broth microdilution method in 96-well microtiter plates (Eppendorf) according to the EUCAST rules for antimicrobial susceptibility testing [35]. The concentrations of test compound ranged from 0.25 to $128 \mu \mathrm{g} / \mathrm{mL}$. The minimal inhibitory concentration was determined as the lowest concentration of antimicrobial for which no visible bacterial growth could be observed after $24 \mathrm{~h}$ of incubation. Then, to determine a minimum bactericidal concentration, a culture liquid from wells without visible growth was diluted a thousand-fold using fresh medium and incubated for $24 \mathrm{~h}$ growth at $35^{\circ} \mathrm{C}$. MBC was assumed as a concentration where no viable cells were observed [36]. The development of bacterial resistance was tested using the serial passages approach as described in [37] with modifications as described in [38].

\subsection{Testing of the Resistance Development}

The bacterial resistance development was tested by using the method of serial passages as described in [37] with modifications. In brief, 96-well plates were seeded with bacterial cells at different concentrations of $\mathbf{F 1 0 5}$ in a liquid medium with following incubation at $37^{\circ} \mathrm{C}$. After $20 \mathrm{~h}$, microorganisms from the last well with a visible growth (with sub-lethal concentration of a compound) were transferred to an antimicrobial-free agar plate. Then, cells from the agar surface were resuspended in a liquid medium and used as inoculum for next seeding into liquid medium with a range of concentrations of antimicrobials. The procedure was repeated to obtain 14 cycles of passages, and MICs of compounds were determined after each one. Then a series of 7 passages on antimicrobial-free agar was done and MICs were again determined. 


\subsection{Synthesis of 2(5H) Furanone Derivatives and General Chemical Experimental Procedures}

The synthesis of F105 was performed as described in [21]. The detailed synthesis of F145 is given in the Supplementary Material. NMR spectra were measured on a Bruker Avance III 400 spectrometer at $400.17 \mathrm{MHz}\left({ }^{1} \mathrm{H}\right)$ and $100.62 \mathrm{MHz}\left({ }^{13} \mathrm{C}\right)$ at $20{ }^{\circ} \mathrm{C}$ in $\mathrm{CDCl}_{3}$. The chemical shifts $(\delta)$ are reported in parts per million (ppm) calibrated on the residual non-deuterated solvent signal. All coupling constants $(J)$ are reported in Hertz (Hz). Multiplicities are indicated as: s (singlet), d (doublet), dd (doublet of doublets), m (multiplet). Analytical thin layer chromatography (TLC) was carried out on Sorbfil PTLC-AF-A-UF plates using UV light $(254 \mathrm{~nm})$ as the visualizing agent. Silica gel $60 \mathrm{~A}$ (Acros Organics, Morristown, NJ, USA, 0.060-0.200 mm) was used for open column chromatography. The melting points were measured on an OptiMelt Stanford Research Systems MPA100 automated melting point apparatus and were not corrected. High-resolution mass spectra (HRMS) were obtained on a Bruker micrOTOF-QIII spectrometer using electron spray ionization (ESI-TOF-MS).

3,4-Dichloro-5-hydroxy-2(5H)-furanone (mucochloric acid, 1) (Vekton, Moscow, Russia) was recrystallized from water, $\mathrm{mp} 127^{\circ} \mathrm{C}$. 4-Methylthiophenol (Alfa Aesar, Ward Hill, MA, USA), 3-chloroperoxybenzoic acid (Acros Organics), and CsF (TCI) were used as received without further purification. All organic solvents were purified and distilled using standard procedures. 3,4-Dichloro-5-methoxycarbonyloxy-2(5H)-furanone (2) [24] and 2-(benzothiazol-2-yl)-4-bromophenol (3) [23] were synthesized according to the previously reported methods. NMR and HRMS spectra are given in the Supplementary Material (Figures S1-S4).

\subsection{Single Crystal X-ray Analysis}

The X-ray diffraction data for the single crystal of 6 were collected on a Bruker Smart Apex II CCD diffractometer ( $\omega$-scan mode) using graphite monochromated MoK $\alpha(0.71073 \AA)$ radiation at $150 \mathrm{~K}$. The structure was solved by the direct methods using SHELXT-2014/5 [39] and refined by the full-matrix least-squares on $F^{2}$ using SHELXL-2017/1 [40]. Calculations were mainly performed using WinGX-2014.1 suite of programs [41]. Non-hydrogen atoms were refined anisotropically. The hydrogen atoms were inserted at the calculated positions and refined as riding atoms.

The crystal data, data collection and structure refinement details for 6 are summarized in Table S1 of the Supplementary Material. The crystallographic data for the investigated crystal 6 have been deposited in the Cambridge Crystallographic Data Centre as supplementary publication CCDC number 1876720. These data can be obtained free of charge via www.ccdc.cam.ac.uk/data_request/cif, by emailing data_request@ccdc.cam.ac.uk, or by contacting The Cambridge Crystallographic Data Centre, 12 Union Road, Cambridge CB2 1EZ, UK; fax: +44 1223336033.

\subsection{Confocal Laser Scanning Microscopy}

Planktonic S. aureus cells were grown for $24 \mathrm{~h}$ with agitation in $\mathrm{MH}$ broth, then washed and resuspended in equal volume of PBS. Next, F145 was added until final concentration of $10 \mu \mathrm{g} / \mathrm{mL}$ and incubated for $15 \mathrm{~min}$, with subsequent additional staining with $5 \mu \mathrm{M} \mathrm{DioC}_{6}$ and $20 \mu \mathrm{M}$ propidium iodide for the next $15 \mathrm{~min}$. S. aureus biofilm was pre-grown for $24 \mathrm{~h}$ in $\mathrm{MH}$ under static conditions and after washing with PBS was stained with $10 \mu \mathrm{M}$ F145 for $1 \mathrm{~h}$. Stained S. aureus cells and biofilm were analyzed under vital conditions using an inverse confocal laser scanning microscope LSM780 (Carl Zeiss AG, Jena, Germany) at blue (405/410-508 nm), green (488/490-606 nm), and red (543/566-718 $\mathrm{nm})$ channels. An area of approximately $100 \mu \mathrm{m}(\mathrm{X}) \times 100 \mu \mathrm{m}(\mathrm{Y})$ was screened in $1 \mu \mathrm{m}$ Z-intervals (Z-stack). The obtained data were visualized using ZEN 9.0 software (Carl Zeiss AG).

\subsection{Atomic Force Microscopy}

S. aureus cells were grown with agitation at $37^{\circ} \mathrm{C}$ in $\mathrm{MH}$ broth in the presence of F105 or BAC for $16-20 \mathrm{~h}$. Then, cells were washed three times with pure water and placed on the cover slide with following air-drying. Atomic force microscopy images of $S$. aureus cells were collected using 
a Dimension Icon Scanning Probe Microscope (Bruker, Billerica, MA, USA) operating in PeakForce Tapping ${ }^{\mathrm{TM}}$ mode at ambient conditions. Scan Asyst-Air probes (Bruker) with nominal length $115 \mu \mathrm{m}$, tip radius $2 \mathrm{~nm}$, and spring constant $0.4 \mathrm{~N} / \mathrm{m}$ were used throughout. The images were obtained at 512 line/scan at $0.8-0.9 \mathrm{~Hz}$ scan rate. The images were acquired in height (topography), peak force error, DMT-modulus and adhesion channels. The raw AFM imaging data obtained were processed and analyzed using Nanoscope Analysis v.1.7 software (Bruker).

\subsection{ROS Detection}

The relative amount of intracellular reactive oxygen species was quantified by using a cell-permeable $2^{\prime}, 7^{\prime}$-dichlorofluorescin diacetate (DCFDA), which is de-esterified intracellularly and turns to highly fluorescent $2^{\prime}, 7^{\prime}$-dichlorofluorescein upon oxidation. Bacteria were grown for $18 \mathrm{~h}$ with agitation, harvested, and washed with PBS. Cells were resuspended until final density of $10^{5} \mathrm{CFU} / \mathrm{mL}$ in PBS supplemented with DCFDA $(5 \mu \mathrm{M})$. After $30 \mathrm{~min}$ pre-incubation at $25^{\circ} \mathrm{C}, 32 \mu \mathrm{g} / \mathrm{mL}$ F105 or $20 \mu \mathrm{M} \mathrm{H}_{2} \mathrm{O}_{2}$ were added, and the fluorescence was measured for $9 \mathrm{~h}$ with 5-min intervals using FAM-filter set detection on Bio-Rad CFX96.

\subsection{Membrane Potential Evaluation}

Membrane potential was evaluated by detection of 3,3'-diethyloxacarbocyanine iodide $\left(\operatorname{DioC}_{2}(3)\right)$ fluorescence. Bacteria were grown for $18 \mathrm{~h}$ in $\mathrm{MH}$ broth with agitation, harvested, and washed with PBS. Cells were resuspended until final density of $10^{5} \mathrm{CFU} / \mathrm{mL}$ in PBS supplemented with 3,3'-diethyloxacarbocyanine iodide $\left(\operatorname{DioC}_{2}(3)\right)$ until final concentration of $10 \mu \mathrm{M}$. After $30 \mathrm{~min}$ preincubation at $25^{\circ} \mathrm{C}, \mathbf{F 1 0 5}$ or BAC were added, and the fluorescence was measured for $30 \mathrm{~min}$ with 5-min intervals using FAM-filter set detection on Bio-Rad CFX96.

\subsection{Proteomic Assays}

The crude extracts of treated and non-treated cells were stained with Cy5 and Cy3 dyes, respectively. Next, the first dimension of two-dimensional gel electrophoresis was performed by using ready IPG gel strips with $\mathrm{pH}$ gradient of 4-7 (Bio-Rad); the second dimension was carried out in 15\%-polyacrylamide gel by [42]. The protein spots were excised from the gel, subjected to in-gel trypsinolysis, and identified using LC-MS/MS on a maXis Impact ${ }^{\mathrm{TM}}$ Mass Spectrometer (Bruker). Polyacrylamide gel electrophoresis under native conditions was performed as described in [42] with IbpA from Acholeplasma laidlawii [43], glutamine synthetase (GS) from Bacillus subtilis [44], DNAase, bovine serum albumin (BSA) from Bos taurus, and bovine liver catalase as model proteins. The Gs activity was measured as described in [44].

\subsection{Statistical Analysis}

The molecular weight, isoelectric point, aliphatic index, charge, hydropathy, and instability index of proteins have been calculated using http:/ / web.expasy.org/compute_pi/ and http:/ /www. camp.bicnirrh.res.in/featcalc/ tools. Next, the distributions of the calculated physical and chemical properties for all proteins interacting with F105 in vivo and in vitro as well as the entire pattern obtained from the $S$. aureus genome were compared using statistical Kolmogorov-Smirnov test as previously [45].

Supplementary Materials: Supplementary materials can be found at http:/ /www.mdpi.com/1422-0067/20/3/ 694/s1. Figure S1: ${ }^{1} \mathrm{H}(\mathrm{a})$ and ${ }^{13} \mathrm{C}\left\{{ }^{1} \mathrm{H}\right\}$ (b) NMR spectra of compound $4\left(\mathrm{CDCl}_{3}\right)$; Figure S2: ${ }^{1} \mathrm{H}(\mathrm{a})$ and ${ }^{13} \mathrm{C}\left\{{ }^{1} \mathrm{H}\right\}(\mathrm{b})$ NMR spectra of compound $5\left(\mathrm{CDCl}_{3}\right)$; Figure S3: ${ }^{1} \mathrm{H}(\mathrm{a})$ and ${ }^{13} \mathrm{C}\left\{{ }^{1} \mathrm{H}\right\}(\mathrm{b}) \mathrm{NMR}$ spectra of compound $6\left(\mathrm{CDCl}_{3}\right)$; Figure S4: Mass spectra of compounds 4-6; Figure S5: 2D electrophoresis of proteome of S. aureus cells treated for 24 hours with sub-lethal concentration $(8 \mu \mathrm{g} / \mathrm{mL}$ ) of F105 (red spots), and untreated (green spots). Overlay of two subpopulations of proteins represents yellow spot; Figure S6: 2D electrophoresis of S. aureus cell crude extracts after 1-hour treatment with F105 $(64 \mu \mathrm{g} / \mathrm{mL})$ (red spots), and untreated (green spots). Overlay of two subpopulations of proteins represents yellow spot; Table S1: Crystal data, data collection and structure refinement details for 6 (F145); Table S2: Intracellular proteins with decreased amount after growth in the presence of F105 
(LC-MS); Table S3: Intracellular proteins with increased amount after growth in the presence of F105 (LC-MS); Table S4: S. aureus proteins with altered mobility after incubation with F105 in vitro.

Author Contributions: Conceptualization-I.S.S. and A.R.K. (Airat R. Kayumov); methodology-I.S.S., A.R.K. (Almira R. Kurbangalieva), and A.R.K. (Airat R. Kayumov); investigation-I.S.S., A.S.P., F.S.A., A.M.K., E.V.R., Y.J.R., and O.A.L.; formal analysis-I.S.S., A.S.P., F.S.A., A.M.K., and A.R.K. (Alsu M. Khabibrakhmanova); resources-R.F., A.R.K. (Almira R. Kurbangalieva), M.B., and A.R.K. (Airat R. Kayumov); visualization-I.S.S., A.S.P., A.M.K., O.A.L., R.F., and M.I.B.; project administration-I.S.S.; supervision- A.R.K. (Airat R. Kayumov); funding acquisition-A.M.K., R.F., M.I.B., and A.M.K.; writing-original draft preparation-I.S.S., A.M.K., and A.R.K. (Airat R. Kayumov); writing-review and editing-A.R.K. (Almira R. Kurbangalieva), M.I.B., R.F., and A.R.K. (Airat R. Kayumov).

Funding: This research was supported by the Russian Foundation for Basic Research (grant No 17-00-00456 to Airat R Kayumov) and by the Ministry of Education and Science of the Russian Federation (assignment 2.5475.2017/6.7 to Mikhail I Bogachev) while being performed in the framework of the Russian Government Program of the Competitive Development of Kazan Federal University. The synthetic part of this work was funded by the subsidy allocated to Kazan Federal University for the state assignment in the sphere of scientific activities (4.1493.2017/4.6 to Almira R Kurbangalieva). The work was partially funded by RFBR grant 18-34-20126-mol-a-ved and by the subsidy allocated to Kazan Federal University for the state assignment in scientific activities (\#16.2822.2017/4.6). The authors gratefully acknowledge the Spectral-Analytical Center of FRC Kazan Scientific Center of RAS for the single crystal X-ray analysis of compound $\mathbf{6}$ and facilities of Interdisciplinary Center for Analytical Microscopy (Kazan Federal University).

Conflicts of Interest: The authors declare no conflicts of interest.

\section{Abbreviations}

$\begin{array}{ll}\text { F105 } & \text { 3-chloro-5(S)-[(1R,2S,5R)-2-isopropyl-5-methylcyclohexyloxy]-4-[4-methylphenylsulfonyl]-2(5H)- } \\ & \text { furanone } \\ \text { F145 } & \text { 5-[2-(Benzothiazol-2-yl)-4-bromophenoxy]-3-chloro-4-[(4-methylphenyl)sulfonyl]-2(5H)-furanone } \\ \text { BAC } & \text { Benzalkonium chloride } \\ \text { CFU } & \text { Colony forming units } \\ \text { RFU } & \text { Relative fluorescence unit } \\ \text { DCFDA } & 2^{\prime}, 7^{\prime} \text {-dichlorofluorescin diacetate } \\ \text { DioC } 2(3) & 3,3^{\prime} \text {-diethyloxacarbocyanine iodide } \\ \text { DCFDA } & 2^{\prime}, 7^{\prime} \text {-dichlorofluorescin diacetate } \\ \text { MBC } & \text { Minimal bactericidal concentration } \\ \text { CLSM } & \text { Confocal laser scanning microscopy } \\ \text { AFM } & \text { Atomic force microscopy } \\ \text { LC-MS } & \text { Liquid Chromatography Mass Spectrometry } \\ \text { MCPBA } & \text { m-Chloroperbenzoic acid } \\ \text { NMR } & \text { Nuclear magnetic resonance spectroscopy } \\ \text { HRMS } & \text { High-resolution mass spectrometry } \\ \text { TLC } & \text { Thin layer chromatography }\end{array}$

\section{References}

1. Hodille, E.; Rose, W.; Diep, B.A.; Goutelle, S.; Lina, G.; Dumitrescu, O. The Role of Antibiotics in Modulating Virulence in Staphylococcus aureus. Clin. Microbiol. Rev. 2017, 30, 887-917. [CrossRef] [PubMed]

2. Di Domenico, E.G.; Farulla, I.; Prignano, G.; Gallo, M.T.; Vespaziani, M.; Cavallo, I.; Sperduti, I.; Pontone, M.; Bordignon, V.; Cilli, L.; et al. Biofilm is a Major Virulence Determinant in Bacterial Colonization of Chronic Skin Ulcers Independently from the Multidrug Resistant Phenotype. Int. J. Mol. Sci. 2017, 18, 1077. [CrossRef] [PubMed]

3. Estrela, A.B.; Abraham, W.-R. Combining Biofilm-Controlling Compounds and Antibiotics as a Promising New Way to Control Biofilm Infections. Pharmaceuticals 2010, 3, 1374-1393. [CrossRef]

4. Chen, M.; Yu, Q.S.; Sun, H.M. Novel Strategies for the Prevention and Treatment of Biofilm Related Infections. Int. J. Mol. Sci. 2013, 14, 18488-18501. [CrossRef] [PubMed]

5. Brackman, G.; Coenye, T. Quorum Sensing Inhibitors as Anti-Biofilm Agents. Curr. Pharm. Des. 2015, 21, 5-11. [CrossRef] 
6. Ren, D.C.; Sims, J.J.; Wood, T.K. Inhibition of biofilm formation and swarming of Escherichia coli by (5Z)-4-bromo-5(bromomethylene)-3-butyl-2(5H)-furanone. Environ. Microbiol. 2001, 3, 731-736. [CrossRef] [PubMed]

7. Ren, D.C.; Bedzyk, L.A.; Setlow, P.; England, D.F.; Kjelleberg, S.; Thomas, S.M.; Ye, R.W.; Wood, T.K. Differential gene expression to investigate the effect of (5Z)-4-bromo-5-(bromomethylene)-3-butyl-2(5H)furanone on Bacillus subtilis. Appl. Environ. Microbiol. 2004, 70, 4941-4949. [CrossRef]

8. Ledl, F.; Beck, J.; Sengl, M.; Osiander, H.; Estendorfer, S.; Severin, T.; Huber, B. Chemical pathways of the Maillard reaction. Prog. Clin. Biol. Res. 1989, 304, $23-42$.

9. Yujie, L.; Geng, X.; Huang, Y.C.; Li, Y.; Yang, K.Y.; Ye, L.H.; Chen, X.B.; Zhao, G.Q.; Yin, C. The Effect of Brominated Furanones on The Formation of Staphylococcus aureus Biofilm on PVC. Cell Biochem. Biophys. 2013, 67, 1501-1505. [CrossRef]

10. Ngwane, A.H.; Panayides, J.L.; Chouteau, F.; Macingwana, L.; Viljoen, A.; Baker, B.; Madikane, E.; de Kock, C.; Wiesner, L.; Chibale, K.; et al. Design, synthesis, and In vitro antituberculosis activity of $2(5 H)$-Furanone derivatives. IUBMB Life 2016, 68, 612-620. [CrossRef]

11. Gondela, E.; Walczak, K.Z. Synthesis and preliminary bioactivity assays of 3,4-dichloro-5-(omegahydroxyalkylamino)-2(5H)-furanones. Eur. J. Med. Chem. 2010, 45, 3993-3997. [CrossRef] [PubMed]

12. Hentzer, M.; Riedel, K.; Rasmussen, T.B.; Heydorn, A.; Andersen, J.B.; Parsek, M.R.; Rice, S.A.; Eberl, L.; Molin, S.; Hoiby, N.; et al. Inhibition of quorum sensing in Pseudomonas aeruginosa biofilm bacteria by a halogenated furanone compound. Microbiology 2002, 148, 87-102. [CrossRef] [PubMed]

13. Lonn-Stensrud, J.; Landin, M.A.; Benneche, T.; Petersen, F.C.; Scheie, A.A. Furanones, potential agents for preventing Staphylococcus epidermidis biofilm infections? J. Antimicrob. Chemother. 2009, 63, 309-316. [CrossRef] [PubMed]

14. Trizna, E.Y.; Khakimullina, E.N.; Latypova, L.Z.; Kurbangalieva, A.R.; Sharafutdinov, I.S.; Evtyugin, V.G.; Babynin, E.V.; Bogachev, M.I.; Kayumov, A.R. Thio Derivatives of 2(5H)-Furanone As Inhibitors against Bacillus subtilis Biofilms. Acta Nat. 2015, 7, 102-107.

15. Manefield, M.; de Nys, R.; Kumar, N.; Read, R.; Givskov, M.; Steinberg, P.; Kjelleberg, S.A. Evidence that halogenated furanones from Delisea pulchra inhibit acylated homoserine lactone (AHL)-mediated gene expression by displacing the AHL signal from its receptor protein. Microbiology 1999, 145, 283-291. [CrossRef] [PubMed]

16. Manefield, M.; Harris, L.; Rice, S.A.; De Nys, R.; Kjelleberg, S. Inhibition of luminescence and virulence in the black tiger prawn (Penaeus monodon) pathogen Vibrio harveyi by intercellular signal antagonists. Appl. Environ. Microbiol. 2000, 66, 2079-2084. [CrossRef] [PubMed]

17. Manefield, M.; Rasmussen, T.B.; Henzter, M.; Andersen, J.B.; Steinberg, P.; Kjelleberg, S.; Givskov, M. Halogenated furanones inhibit quorum sensing through accelerated LuxR turnover. Microbiology 2002, 148, 1119-1127. [CrossRef] [PubMed]

18. Kayumov, A.R.; Khakimullina, E.N.; Sharafutdinov, I.S.; Trizna, E.Y.; Latypova, L.Z.; Hoang Thi, L.; Margulis, A.B.; Bogachev, M.I.; Kurbangalieva, A.R. Inhibition of biofilm formation in Bacillus subtilis by new halogenated furanones. J. Antibiot. 2015, 68, 297-301. [CrossRef]

19. Zang, T.Z.; Lee, B.W.K.; Cannon, L.M.; Ritter, K.A.; Dai, S.J.; Ren, D.C.; Wood, T.K.; Zhou, Z.S. A naturally occurring brominated furanone covalently modifies and inactivates LuxS. Bioorg. Med. Chem. Lett. 2009, 19, 6200-6204. [CrossRef]

20. Kuehl, R.; Al-Bataineh, S.; Gordon, O.; Luginbuehl, R.; Otto, M.; Textor, M.; Landmann, R. Furanone at Subinhibitory Concentrations Enhances Staphylococcal Biofilm Formation by luxS Repression. Antimicrob. Agents Chemother. 2009, 53, 4159-4166. [CrossRef]

21. Sharafutdinov, I.S.; Trizna, E.Y.; Baidamshina, D.R.; Ryzhikova, M.N.; Sibgatullina, R.R.; Khabibrakhmanova, A.M.; Latypova, L.Z.; Kurbangalieva, A.R.; Rozhina, E.V.; Klinger-Strobel, M.; et al. Antimicrobial Effects of Sulfonyl Derivative of 2(5H)-Furanone against Planktonic and Biofilm Associated Methicillin-Resistant and -Susceptible Staphylococcus aureus. Front. Microbiol. 2017, 8. [CrossRef] [PubMed]

22. Trizna, E.; Latypova, L.; Kurbangalieva, A.; Bogachev, M.; Kayumov, A. 2(5H)-Furanone Derivatives as Inhibitors of Staphylococcal Biofilms. Bionanoscience 2016. [CrossRef] 
23. Otsubo, T.; Minami, A.; Fujii, H.; Taguchi, R.; Takahashi, T.; Suzuki, T.; Teraoka, F.; Ikeda, K. 2-(Benzothiazol-2-yl)-phenyl-beta-D-galactopyranoside derivatives as fluorescent pigment dyeing substrates and their application for the assay of beta-D-galactosidase activities. Bioorg. Med. Chem. Lett. 2013, 23, 2245-2249. [CrossRef] [PubMed]

24. Blazecka, P.G.; Belmont, D.; Curran, T.; Pflum, D.; Zhang, J. Further utilization of mucohalic acids: Palladium-free, regioselective etherification and amination of alpha, beta-dihalo gamma-methoxycarbonyloxy and gamma-acetoxy butenolides. Org. Lett. 2003, 5, 5015-5017. [CrossRef]

25. Kurbangalieva, A.R.; Lodochnikova, O.A.; Devyatova, N.F.; Berdnikov, E.A.; Gnezdilov, O.I.; Litvinov, I.A.; Chmutova, G.A. Structural diversity of interaction products of mucochloric acid and its derivatives with 1,2-ethanedithiol. Tetrahedron 2010, 66, 9945-9953. [CrossRef]

26. Kurbangalieva, A.R.; Devyatova, N.F.; Bogdanov, A.V.; Berdnikov, E.A.; Mannafov, T.G.; Krivolapov, D.B.; Litvinov, I.A.; Chmutova, G.A. Synthesis of novel arylthio derivatives of mucochloric acid. Phosphorus Sulfur Silicon Relat. Elem. 2007, 182, 607-630. [CrossRef]

27. Latypova, L.Z.; Saigitbatalova, E.S.; Chulakova, D.R.; Lodochnikova, O.A.; Kurbangalieva, A.R.; Berdnikov, E.A.; Chmutova, G.A. Sulfides, sulfones, and sulfoxides of the furan-2(5H)-one series. synthesis and structure. Russ. J. Org. Chem. 2014, 50, 521-534. [CrossRef]

28. Braoudaki, M.; Hilton, A.C. Mechanisms of resistance in Salmonella enterica adapted to erythromycin, benzalkonium chloride and triclosan. Int. J. Antimicrob. Agents 2005, 25, 31-37. [CrossRef]

29. Kamatou, G.P.; Vermaak, I.; Viljoen, A.M.; Lawrence, B.M. Menthol: A simple monoterpene with remarkable biological properties. Phytochemistry 2013, 96, 15-25. [CrossRef]

30. Narishetty, S.T.; Panchagnula, R. Effect of L-menthol and 1,8-cineole on phase behavior and molecular organization of SC lipids and skin permeation of zidovudine. J. Control. Release 2005, 102, 59-70. [CrossRef] [PubMed]

31. Zhou, G.; Shi, Q.S.; Huang, X.M.; Xie, X.B. The Three Bacterial Lines of Defense against Antimicrobial Agents. Int. J. Mol. Sci. 2015, 16, 21711-21733. [CrossRef] [PubMed]

32. Dryden, M.S.; Cooke, J.; Salib, R.J.; Holding, R.E.; Biggs, T.; Salamat, A.A.; Allan, R.N.; Newby, R.S.; Halstead, F.; Oppenheim, B.; et al. Reactive oxygen: A novel antimicrobial mechanism for targeting biofilm-associated infection. J. Glob. Antimicrob. Resist. 2017, 8, 186-191. [CrossRef] [PubMed]

33. Forrest, G.N.; Tamura, K. Rifampin Combination Therapy for Nonmycobacterial Infections. Clin. Microbiol. Rev. 2010, 23, 14-34. [CrossRef] [PubMed]

34. Mo, Y.Q.; Wang, Z.Y.; Mei, W.J.; Fu, J.H.; Tan, Y.H.; Luo, S.H. Reaction of 5-alkoxy-3,4-dihalo-2(5H)-furanones with secondary amines: Expected versus unanticipated products and their preliminary bioactivity investigations. Monatshefte Chem. 2012, 143, 443-453. [CrossRef]

35. Leclercq, R.; Canton, R.; Brown, D.F.; Giske, C.G.; Heisig, P.; MacGowan, A.P.; Mouton, J.W.; Nordmann, P.; Rodloff, A.C.; Rossolini, G.M.; et al. EUCAST expert rules in antimicrobial susceptibility testing. Clin. Microbiol. Infect. 2013, 19, 141-160. [CrossRef] [PubMed]

36. European Committee for Antimicrobial Susceptibility Testing (EUCAST) of the European Society of Clinical Microbiology and Infectious Dieases (ESCMID). EUCAST Definitive Document E.Def 1.2, May 2000: Terminology relating to methods for the determination of susceptibility of bacteria to antimicrobial agents. Clin. Microbiol. Infect. 2000, 6, 503-508. [CrossRef]

37. Locher, H.H.; Caspers, P.; Bruyere, T.; Schroeder, S.; Pfaff, P.; Knezevic, A.; Keck, W.; Ritz, D. Investigations of the Mode of Action and Resistance Development of Cadazolid, a New Antibiotic for Treatment of Clostridium difficile Infections. Antimicrob. Agents Chemother. 2014, 58, 901-908. [CrossRef]

38. Sharafutdinov, I.S.; Pavlova, A.S.; Khabibrakhmanova, A.M.; Faizova, G.M.; Kurbangalieva, A.R.; Katsunori, T.; Trizna, E.Y.; Baidamshina, D.R.; Bogachev, M.I.; Kayumov, A.R. Targeting Bacillus cereus cells: Increasing efficiency of antimicrobials by the bornyl-possessing 2(5H)-furanone derivative. New Microbiol. 2019, 42, Epub ahead of print. [PubMed]

39. Sheldrick, G.M. SHELXT-Integrated space-group and crystal-structure determination. Acta Crystallogr. Sect. A Found. Adv. 2015, 71, 3-8. [CrossRef]

40. Sheldrick, G.M. Crystal structure refinement with SHELXL. Acta Crystallogr. Sect. C Struct. Chem. 2015, 71, 3-8. [CrossRef]

41. Farrugia, L.J. WinGX and ORTEP for Windows: An update. J. Appl. Crystallogr. 2012, 45, 849-854. [CrossRef] 
42. Laemmli, U.K. Cleavage of structural proteins during assembly of head of bacteriophage-T4. Nature 1970, 227, 680-685. [CrossRef] [PubMed]

43. Vishnyakov, I.E.; Levitskii, S.A.; Manuvera, V.A.; Lazarev, V.N.; Ayala, J.A.; Ivanov, V.A.; Snigirevskaya, E.S.; Komissarchik, Y.Y.; Borchsenius, S.N. The identification and characterization of IbpA, a novel alpha-crystallin-type heat shock protein from mycoplasma. Cell Stress Chaperones 2012, 17, 171-180. [CrossRef] [PubMed]

44. Hauf, K.; Kayumov, A.; Gloge, F.; Forchhammer, K. The Molecular Basis of TnrA Control by Glutamine Synthetase in Bacillus subtilis. J. Biol. Chem. 2016, 291, 3483-3495. [CrossRef] [PubMed]

45. Vishnyakov, I.E.; Bogachev, M.I.; Salafutdinov, I.; Borchsenius, S.N.; Kayumov, A.R. The Temperature-Dependent Selectivity of Potential Interaction Partners for the Small Heat Shock Protein IbpA from Acholeplasma laidlawii. Bionanoscience 2016, 6, 437-442. [CrossRef]

(C) 2019 by the authors. Licensee MDPI, Basel, Switzerland. This article is an open access article distributed under the terms and conditions of the Creative Commons Attribution (CC BY) license (http:/ / creativecommons.org/licenses/by/4.0/). 